\title{
SEASONAL GROWTH AND REPRODUCTION OF GELIDIOPSIS VARIABILIS (Greville) Schmitz
}

\author{
N. Kaliaperumal ${ }^{1}$ and M. Umamaheswara Rao \\ Department of Botany, Andhra University, Waltair 530003, India
}

\begin{abstract}
Seasonal variations in growth, fruiting, and sporulation of Gelidiopsis variabilis (Greville) Schmitz occurring on the Visakhapatnam coast have been described. Only tetrasporophytes and vegetative plants were found in the populations analysed for $2 \frac{1}{2} \mathrm{yr}$ and seasonal changes were more marked in the abundance of tetrasporophytes, formation of stichidia, and in the spore output, than in the stature of the plants. Maximum development of the plants was observed each year between October and January-February and peak reproductive activity from July to September.
\end{abstract}

\section{INTRODUCTION}

Gelidiopsis variabilis, a member of the Gigartinales, occurs infrequently in intertidal habitats on the Indian coast (Krishnamurthy \& Joshi, 1970). As little is known on the ecology and life history of this red alga confined to the warmer parts of the sea, detailed investigations were made on the populations found along the Visakhapatnam coast. The present account deals with the information collected on seasonal aspects of growth, fruiting periodicity, and spore-shedding for a period of $2 \frac{1}{2} \mathrm{yr}$ from September 1976 to February 1979.

\section{MATERIAL AND METHODS}

Plants of G. variabilis (Greville) Schmitz, which grow as wiry tufts in the mixed algal turf of the infralittoral fringe, were collected from three stations along the coastline of Visakhapatnam $\left(17^{\circ} 41^{\prime} 45^{\prime \prime} \mathrm{N}: 83^{\circ} 16^{\prime} 22^{\prime \prime} \mathrm{E}\right)$. From each station, 10-15 clumps or tufts of $G$. variabilis were randomly collected at 15 -day intervals during low tide periods. They were brought to the laboratory in polythene bags filled with sea water for growth analysis and spore-shedding experiments. The fruiting and vegetative or undeterminable plants in the samples, collected at each station were then separated. The length of 20 to 25 erect shoots was measured (selecting randomly) from each tuft of the vegetative and tetrasporic plants present in the samples to determine the seasonal changes in the stature of the fronds of vegetative plants, tetrasporophytes, and also of the total

\footnotetext{
1 Present address: Regional Centre of Central Marine Fisheries Research Institute, Mandapam Camp, Tamil Nadu, India.
} 
population. The erect fronds measured were divided into the following groups: Group I $(<4 \mathrm{~cm})$, Group II $(4-8 \mathrm{~cm})$, and Group III $(>8 \mathrm{~cm})$, for estimating the relative abundance of different size classes in the population. Data collected at 15-day intervals from different stations were pooled together for each month $(n=60-90)$, since there were no significant differences between the two samples collected in a month and between the samples of three stations.

Using the same samples, information on fresh weight of two to three tetrasporophytes and the number of tetrasporangial stichidia occurring on these plants was obtained to calculate the seasonal abundance of stichidia per $\mathrm{g}$ fresh wt of the plant.

Two fully developed stichidia with mature tetrasporangia were used for estimating the spore production from stichidia. After thorough cleaning and washing, the stichidia were placed in small Petri dishes filled with $15 \mathrm{ml}$ of sterilized sea water and tetraspores liberated per day were counted following the method described by Umamaheswara Rao (1979). Every month 12 experiments were conducted for spore output estimation, at room temperature and near a light source of 500 lux under $8: \overline{16} \mathrm{LD}$ cycle. Spore output data collected on the first day of the experiments are finally expressed as spores liberated per $\mathrm{g}$ fresh wt of the plant material.

\section{RESUlts}

\section{SEASONAL GROWTH BEHAVIOUR}

Results obtained on monthly measurements of frond length in the entire population, tetrasporophytes and vegetative plants of G. variabilis and also on the percentage frequency of the three size classes of erect fronds are shown in Fig. 1. Although a distinct annual pattern was not seen in the stature of the plants (Fig. 1A), maximum increase in length of the erect shoots was observed during October to January-February each year. The $t$ value calculated from the data obtained during this period and during other months of the year, was significant $(5.786)$ at the $5 \%$ level $($ d.f. $=10)$ in 1976-1977 and not significant (1.696) in 1977-1978. In 1977-1978, although rapid increase in frond length was observed in October, this was not seen in the next few months. In the data presented on vegetative plants (Fig. 1C), seasonal changes in stature were somewhat distinct with three periods of maximum development between September 1976 and February 1979, whereas the seasonal events in frond length were not clear in the tetrasporophytic phase of this alga (Fig. 1B).

Data on seasonal abundance of fronds of the three size classes are shown in Fig. 1D. Maximum percentage (55.6-80.0) of Group I fronds was found during March to June-July, while Group II and Group III fronds occurred in maximum numbers in the population from October to January-February. These variations in the size classes of erect shoots also suggest that there is a single annual peak growth in G. variabilis. 


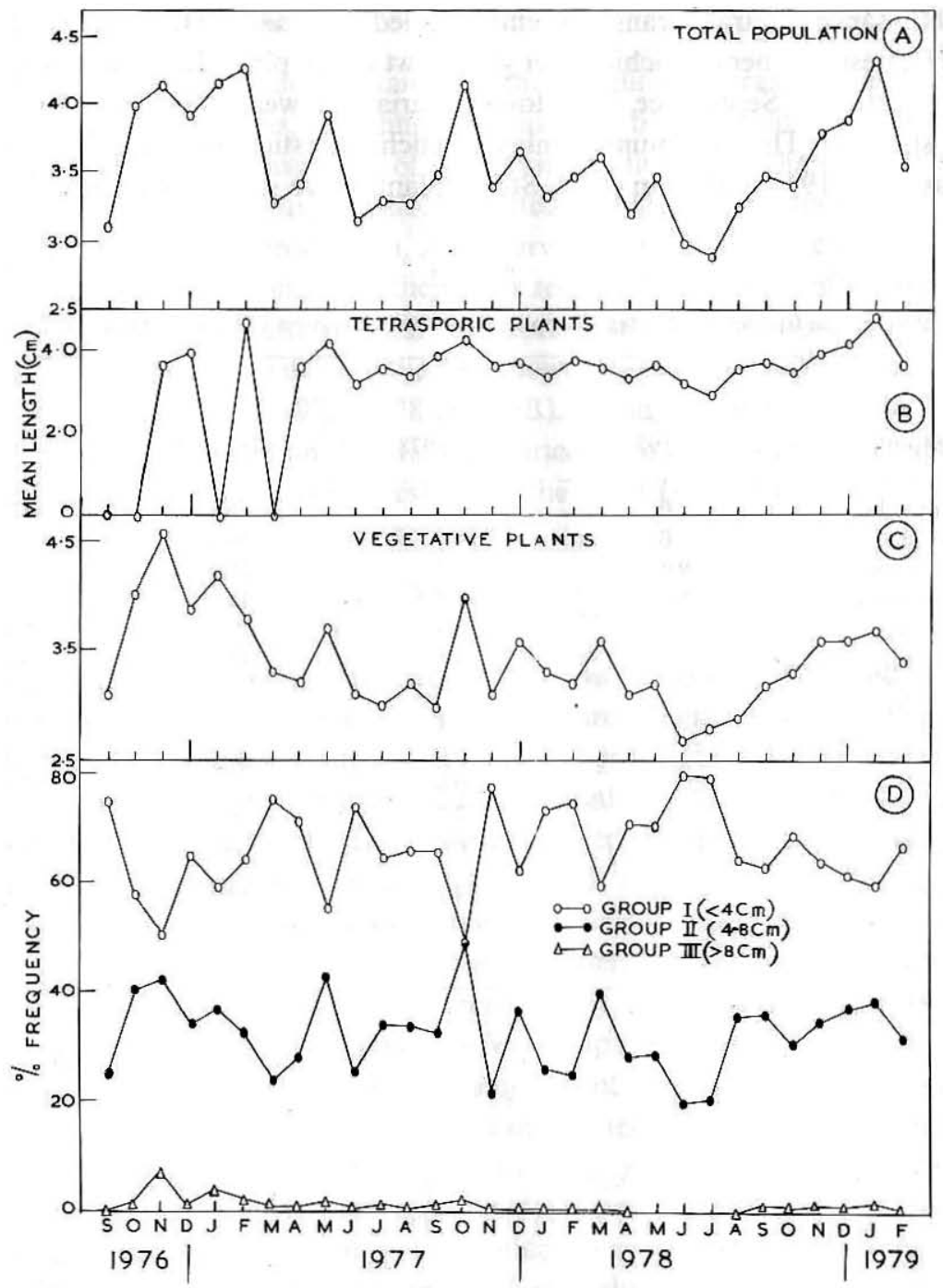

Fig. 1. Seasonal changes in length and frequency of three size classes of fronds of Gelidiopsis variabilis.

\section{FRUITING PERIODICITY}

Monthly and yearly mean values obtained on the abundance of tetrasporophytes in the natural population of $G$. variabilis are shown in Table I. Sexual plants were not seen in the samples of this alga collected during the 30 months in the present study. In contrast to the data obtained on frond length, seasonal variations were observed in the population of tetrasporophytes with the maximum number between July and September and the minimum between November and March. 
The abundance of tetrasporangial stichidia varied seasonally in G. variabilis (Fig. 2A), with the highest number of stichidia per $\mathrm{g}$ fresh wt of the plant during the peak fruiting season from July to September. Year-to-year variations were also seen in the development of stichidia. The maximum number of stichidia estimated per $\mathrm{g}$ fresh wt of the plant was 68 in 1977 and 25 in 1978. Sterile plants were seen at the beginning of this study in 1976.

TABLE I

Percentage frequency of tetrasporophytes in the population of Gelidiopsis variabilis.

\begin{tabular}{lcccc}
\hline & \multicolumn{4}{c}{ Year } \\
\cline { 2 - 3 } Month & $1976-1977$ & $1977-1978$ & $1978-1979$ & Mean \\
\hline September & 0 & 58.5 & 76.1 & 44.9 \\
October & 0 & 36.2 & 69.2 & 35.2 \\
November & 9.0 & 28.2 & 28.4 & 21.9 \\
December & 5.0 & 13.5 & 15.9 & 11.5 \\
January & 0 & 13.8 & 12.5 & 8.8 \\
February & 1.2 & 24.2 & 37.1 & 20.9 \\
March & 0 & 12.5 & - & 6.2 \\
April & 32.6 & 39.1 & - & 35.9 \\
May & 51.0 & 10.0 & - & 30.5 \\
June & 29.8 & 50.0 & - & 39.9 \\
July & 72.0 & 57.5 & - & 64.8 \\
August & 85.0 & 70.0 & 39.9 & 32.5 \\
Mean & 23.8 & 34.5 & & 32.7 \\
\hline
\end{tabular}

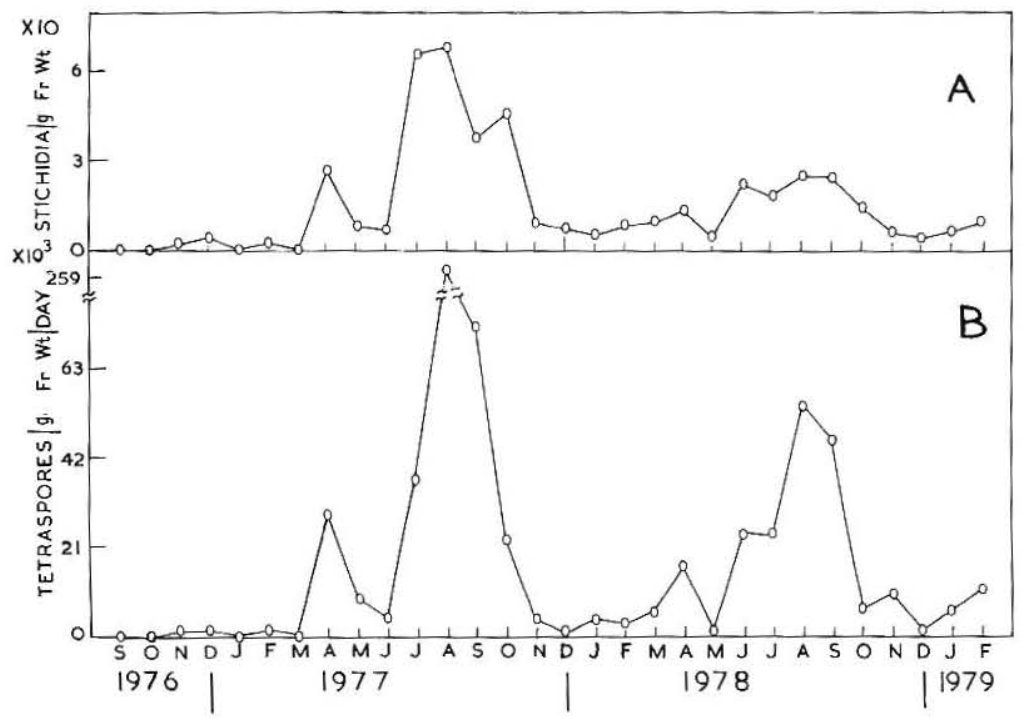

Fig. 2. Seasonal variations in the number of stichidia and tetraspore output on the first day in Gelidiopsis variabilis. 


\section{SEASONAL SPORE-SHEDDING}

Fig. 2B summarizes the results obtained on the shedding of tetraspores in G. variabilis. Under laboratory conditions, shedding of tetraspores from stichidia was observed for 3-4 days, with maximum discharge of spores on the first day. The number of spores liberated on the first day was, therefore, plotted in Fig. 2B, and found to follow the monthly changes in spore production. As observed in the abundance of fruiting plants and stichidia, clearcut seasonal periodicity was seen in the liberation of tetraspores with a single peak shedding period from July to September. Slight increase in spore output as well as in the abundance of stichidia was, however, seen in April during the fruiting seasons of 1976-1977 and 1977-1978 (Fig. 2B). During the period of this study, the quantity of spores liberated on the first day varied from a low value of 20 spores to a maximum of 260940 spores per $g$ fresh wt of the plant (Fig. 2B).

\section{Discussion}

Previously little was known of the ecology of $G$. variabilis growing in India and other tropical areas. It is now evident that it occurs throughout the year in the intertidal habitats of Visakhapatnam coast, with a unimodal growth and reproductive cycle in a year. The seasonal changes observed in frond length were very irregular without any prominent peak and there were no differences either in the annual cycle of vegetative plants or in the tetrasporophytic stages in the life history of this alga. G. variabilis appears to be a slow-growing plant and the mean values obtained on the length of the fronds range from 2.89 to $4.33 \mathrm{~cm}$ during the entire period of this investigation (Fig. 1A). This irregular pattern observed in G. variabilis may be due to slow growth rate and sparse occurrence of the plants along the Visakhapatnam coast.

Results on growth and reproductive phenology of G. variabilis clearly indicate that the behaviour of the plant is different from other members of the Gigartinales found on the Visakhapatnam coast. In Gracilaria corticata and Hypnea valentiae (Subbarangaiah, 1978) two maxima were observed in the vegetative growth and spore-shedding periods with a half-yearly growth and reproductive cycles, while in $G$. variabilis maximum increase in length of the fronds and peak reproductive activity was seen only once during the year (Figs. 1 and 2). In certain Gigartinales members such as Gracilaria verrucosa (Jones, 1959), Gracilariopsis sjoestedtii (Umamaheswara Rao, 1973a), and Gigartina stellata (Burns \& Mathieson, 1972), seasonal production of reproductive elements was related to seasonal maximum vegetative growth. Such a relationship was not observed in the present study and in this respect Gelidiopsis variabilis agrees with Gracilaria bursapastoris (Hoyle, 1978) growing at Hawaii.

In the absence of gametangial plants and in the occurrence of tetrasporophytic phase in the natural population, Gelidiopsis variabilis is similar to Gelidiella acerosa (Umamaheswara Rao, 1973b), Antithamnion boreale (Sundene, 1962), and other red algae (Dixon, 1970). The importance of perennation and vegetative propagation, when one 
or more phases in the life cycle of an alga occur, in the field, was emphasized by Dixon $(1965,1970)$. Development of fresh shoots from vegetative fragments maintained in the laboratory (unpubl.) suggests that Gelidiopsis variabilis can survive in the intertidal habitats by vegetative propagation or by regeneration from the basal parts of the plants. Detailed culture studies are, however, needed to find out the nature of spores released by the tetrasporangial plants of $G$. variabilis and to detect the missing gametophytic phases in the life cycle of this alga.

\section{ACKNOWLEDGEMENTS}

One of the authors (N.K.) is grateful to Dr. V.A. Parasuraman for financial help and also to the Council of Scientific and Industrial Research, New Delhi, for the award of Senior Research Fellowship during the period of this investigation.

\section{REFERENCES}

Burns, R.L. \& A.C. Mathieson, 1972. Ecological studies of economic red algae. III. Growth and reproduction of natural and harvested populations of Gigartina stellata (Stackhouse) Batters in New Hampshire. J. Exp. Mar. Biol. Ecol., Vol. 9, pp. 77-95.

Dixon, P.S., 1965. Perennation, vegetative propagation and algal life histories with special reference to Asparagopsis and other Rhodophyta. Bot. Gothob. Acta Univ. Gothob., Vol. 3, pp. 67-74.

Dixon, P.S., 1970. The Rhodophyta. Some aspects of their biology. II. Oceanogr. Mar. Biol. Ann. Rev., Vol. 8, pp. 307-352.

Hoyle, M.D., 1978. Reproductive phenology and growth rates in two species of Gracilaria from Hawaii. J. Exp. Mar. Biol. Ecol., Vol. 35, pp. 273-283.

Jones, W.E., 1959. The growth and fruiting of Gracilaria verrucosa (Hudson) Papenfuss. J. Mar. Biol. Assoc. U.K., Vol. 38, pp. 47-56.

Krishnamurthy, V. \& H.V. Joshi, 1970. A check list of Indian marine algae. CSMCRI, Bhavnagar, India, $36 \mathrm{pp}$.

Subbarangaiah, G., 1978. Studies on the autecology of some Gigartinales of the Visakhapatnam coast. Ph.D. thesis, Andhra University, India, $128 \mathrm{pp}$.

SUNDENE, O., 1962. Reproduction and morphology in strains of Antithamnion boreale originating from Spitsbergen and Scandinavia. Skr. Nor. Vidensk. Akad. Oslo, I. Mat-Nat. KI. N.S., Vol. 5, pp. 1-19.

UMAMAHESWARA RAO, M., 1973a. Growth and reproduction in some species of Gracilaria and Gracilariopsis in Palk Bay. Indian J. Fish., Vol. 20, pp. 182-192.

Umamaheswara Rao, M., 1973b. Growth and reproduction of Gelidiella acerosa in the Palk Bay and Gulf of Mannar near Mandapam. Indian J. Fish., Vol. 20, pp. 411-416.

UmAmAHeswara RAO, M., in press. Growth, reproduction and spore shedding in Grateloupia filicina (Wulfen) C. Agardh. Proc. Int. Symp. Marine Algae of the Indian Ocean Region, CSMCRI, Bhavnagar, India, in press. 